\title{
Secret talk between adipose tissue and central nervous system via secreted factors-an emerging frontier in the neurodegenerative research
}

\author{
Avinash Parimisetty ${ }^{1,2}$, Anne-Claire Dorsemans ${ }^{1,2}$, Rana Awada ${ }^{3}$, Palaniyandi Ravanan ${ }^{4}$, Nicolas Diotel ${ }^{1,2+}$ \\ and Christian Lefebvre $d^{\prime} H e l l e n c o u r t 2^{1,2^{*}}$
}

\begin{abstract}
First seen as a storage organ, the white adipose tissue (WAT) is now considered as an endocrine organ. WAT can produce an array of bioactive factors known as adipokines acting at physiological level and playing a vital role in energy metabolism as well as in immune response. The global effect of adipokines in metabolic activities is well established, but their impact on the physiology and the pathophysiology of the central nervous system (CNS) remains poorly defined. Adipokines are not only produced by the WAT but can also be expressed in the CNS where receptors for these factors are present. When produced in periphery and to affect the CNS, these factors may either cross the blood brain barrier (BBB) or modify the BBB physiology by acting on cells forming the BBB. Adipokines could regulate neuroinflammation and oxidative stress which are two major physiological processes involved in neurodegeneration and are associated with many chronic neurodegenerative diseases. In this review, we focus on four important adipokines (leptin, resistin, adiponectin, and TNFa) and one lipokine (lysophosphatidic acid—LPA) associated with autotaxin, its producing enzyme. Their potential effects on neurodegeneration and brain repair (neurogenesis) will be discussed. Understanding and regulating these adipokines could be an interesting lead to novel therapeutic strategy in order to counteract neurodegenerative disorders and/or promote brain repair.
\end{abstract}

Keywords: Diabetes, Obesity, White adipose tissue, Adipocytokines, Central nervous system, Neuroinflammation, Neurodegeneration, Neurogenesis

\section{Background}

Obesity and type 2 diabetes mellitus (T2DM) are main health issues in our modern societies and constitute very important public health challenges [1-3]. The World Health Organization (WHO) reported that worldwide obesity has more than doubled since 1980 and more than 1.9 billion adults were overweight in 2014 [2]. One result from excess body weight and physical inactivity is the dramatic development of type 2 diabetes that WHO has predicted to be the seventh leading cause of death in

\footnotetext{
* Correspondence: Christian.Lefebvre-d-Hellencourt@univ-reunion.fr ${ }^{\dagger}$ Equal contributors

${ }^{1}$ Université de La Réunion, UMR 1188, Sainte-Clotilde F-97490, France 2Inserm, UMR 1188 Diabète athérothrombose Thérapies Réunion Océan Indien (DéTROI), plateforme CYROI, Sainte-Clotilde F-97490, France

Full list of author information is available at the end of the article
}

2030 [3-5]. In parallel, 35.6 million people display dementia and 7.7 million new cases are reported every year, Alzheimer's disease (AD) being the main cause of dementia [6,7]. An increasing number of data recently highlights that metabolic syndrome, notably obesity and type 2 diabetes, are correlated with an increased risk to develop dementia and/or neurodegenerative diseases such as $\mathrm{AD}$, as well as neurological and neurovascular disorders [8-11]. Consequently, adiposity has been proposed as an independent factor favoring the development of AD [12-14]. However, breaking the paradigm, recent studies show that underweight people $(\mathrm{BMI}<20 \mathrm{~kg} / \mathrm{m} 2)$ display higher risk of dementia while very obese people (BMI $>40 \mathrm{~kg} / \mathrm{m} 2)$ have lower dementia risk than healthy weight people [15]. Similarly, a decrease in BMI from mid-life to late-life has 
been correlated with an increased risk of dementia [16]. Interestingly, it has been suggested that the misexpression of adipose-derived factors called adipokines or adipocytokines may disrupt directly or indirectly brain homeostasis and functions.

In this review, we aimed at first describing the links between adiposity, adipokines levels, and neurological disorders. Furthermore, adipokine signaling in the central nervous system (CNS), highlighting their potential effects on cognition, neurogenesis, and brain functioning, has also been explored. Finally, the possibilities of adipokines to disturb brain physiology and functions through blood brain barrier disruption resulting from increased inflammation and oxidative stress have been discussed.

\section{White adipose tissue: not just energy storage White adipose tissue secretes adipokines}

White adipose tissue (WAT) was originally described to store energy in the form of triglycerides. However, since the discovery of the leptin hormone in 1994, WAT is also recognized as a major endocrine organ secreting a wide variety of biologically active factors collectively called adipokines or adipocytokines [17, 18]. To date, about hundred adipokines constituting the adipokinome have been documented to be released from white adipocytes [19]. The most studied adipokines are leptin, adiponectin, apelin, resistin, monocytes, and macrophage

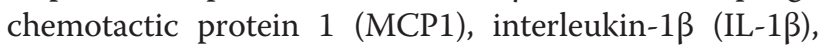
interleukin-6 (IL-6), interleukin-10 (IL-10), tumor necrosis factor-alpha (TNF $\alpha)$, and transforming growth factor (TGF $\beta)$. In addition to adipokines, lipid-derived factors (sometimes referred as lipokines) such as the lysophosphatidic acid are also important mediators produced by the fat tissue [20, 21]. Pro-inflammatory factors include adipokines such as leptin, TNF $\alpha$, and IL-6, while antiinflammatory ones include adiponectin and the secreted frizzled-related protein 5 (sFRP5) [20, 22, 23]. Adipokines exert pleiotropic effects on different tissues such as the lung, skeletal muscle, heart, liver, and blood vessels and regulate numerous physiological functions such as appetite, energy expenditure, insulin sensitivity and secretion, fat distribution, lipid and glucose metabolism, endothelial function, blood pressure, hemostasis, neuroendocrine functions, and also immunity [18, 21, 24-28]. The data generated over the last 20 years considerably change our view on adipose tissue as WAT plays a wideranging role in metabolic regulation and physiological homeostasis $[17,18]$.

\section{Adipokines and diseases: focus on neurological disorders and diseases}

The dysregulation of adipokine production and/or levels has been correlated with several diseases and could notably promote and/or result in obesity-linked metabolic disorders $[27,29]$. Thus, low plasmatic leptin concentrations are associated with an increased risk for cardiovascular diseases [30]. In contrast, higher plasmatic adiponectin levels seem to be associated with decreased risk for developing type 2 diabetes mellitus (T2DM) [31]. Other data also show relationships between MCP-1 serum levels and insulin resistance, as diabetic patients exhibit highest MCP-1 levels [32]. In the same line of evidences, it appears that the inflammatory status of WAT in obese patients might be a key player linking high WAT mass to insulin resistance. Interestingly, an increasing number of studies reported links between metabolic disorders (i.e., T2DM and obesity) and brain homeostasis and functioning $[9,12,33-39]$. Initial studies demonstrated that a higher body mass index (BMI) and/or waist-to-hip ratio in middle-aged individuals is associated with a reduction in the whole brain volume. Indeed, over the last decade, a number of magnetic resonance imaging (MRI) and computed tomography (CT) studies also reported alterations in brain morphology of overweight/obese individuals [40-42]. Studies documented a link between abdominal fat and reduced brain volume in healthy middle-aged adults notably the temporal lobe volume and the hippocampus $[43,44]$. In a cross-sectional study of normal elderly individuals showing no sign of cognitive deficit, tensor-based morphometry also unveiled atrophy in the white and gray matter of the frontal lobes, anterior cingulate gyrus, hippocampus, and thalamus in both male and female subjects with a high BMI $(\mathrm{BMI}>30)$ as compared to individuals with a normal BMI (18.5-25) [45]. Upon further investigation, the brain volume reduction in gray and white matter was found to be associated with a common variant of the fat mass and obesity-associated (FTO) gene [46]. In addition, a growing body of studies also show that obesity in mid-life is a predictor of mild cognitive impairment with aging and altered executive function and short-term memory compared to normal weight counterparts [39, 47-49]. Such data were also confirmed in rodents for which high fat diets result in impaired cognitive functions including a decrease in memory performance, learning, and executive functions $[39,50,51]$. Furthermore, during the development of obesity in rodent models, it appears that neurochemical changes occurs in the brain altering cognition processes, reward neurocircuitry, and stress responsiveness [52]. Consequently, numerous studies described association between rich diets (sugar and/or fat) and cognitive defects in rodents and humans $[39,52]$, and it seems that such effects of diets could occur through the disruption of neurovascular function [52-54]. In addition, a linkage has been demonstrated between overweight, neuroinflammation, and neurodegenerative diseases namely $\mathrm{AD}$, Parkinson's disease (PD), and autoimmune nervous system diseases such as multiple sclerosis [9, 12, 33-38]. 
Similarly, T2DM is associated to impaired cognition, especially learning and memory deficits such as shown in rodents and humans while such effects are rarely observed in type 1 diabetes $[55,56]$. This is peculiarly interesting given that T2DM patients are mostly overweight or obese compared to type 1 diabetic. In a recent study, working on 80 T2DM patients and 80 healthy controls demonstrated a cortical and subcortical atrophy and that cognition impairment was correlated with reduced hippocampal CA1 size in the diabetic group [57]. Diabetes is associated with an increased risk of $\mathrm{AD}$ and vascular dementia, supported by increasing oxidative stress and inflammation and impaired insulin and amyloid metabolisms [56, 58-62]. T2DM patients also display lower cerebral blood flow and neural slowing on recordings of sensory-evoked potentials [56]. Numerous studies performed on rodents also show an impact of diabetes on neurogenesis, depression, and cognition [63].

Taken together, these data show that obesity and diabetes have negative effects on brain structures and/or functions. It also raises the question about the roles of adipokines in such neurological disorders. A possible explanation could be that abnormal adipokine concentrations, such as increase pro-inflammatory adipokines TNF $\alpha$, resistin, leptin, IL-1 $\beta$, and also IL-6, could influence the blood brain barrier integrity and disrupt brain homeostasis through oxidative stress and inflammation $[12,20]$. In the following part, we aim to describe the effects of some adipokines in the brain, regarding their transport in the central nervous system and their signaling.

\section{Adipokines and targets in the brain}

In this part, we focus on specific adipokines (leptin, resistin, adiponectin, TNF $\alpha$ ) and also on a lipokine of interest, the lysophosphatidic acid (LPA) and their targets in the brain as well as their potential impact on brain inflammation and functions (Fig. 1).

\section{Leptin}

Leptin is probably the most studied adipose-derived hormones. Leptin which is mainly produced by adipocytes exerts its effects both peripherally and centrally $[17,21,24,64]$. This adipokine plays a key role in regulating energy intake and expenditure, metabolism, and behavior by directly acting on the CNS. Mice invalidated for leptin (ob/ob mice) display obesity, insulin resistance, and hyperphagia showing notably the impact of this adipose-derived hormone on feeding behavior [65]. Peripheral leptin exerts its central effect through its binding at the level of choroid plexus leading to its transport across the blood brain barrier [66-69]. Such a transport involved leptin receptors and probably other mechanisms that are still poorly understood [9]. However, some studies have shown that leptin could be also locally and de novo produced in the brain, in the cerebellum, the cortex, and the hypothalamus [70-73], suggesting other specific and

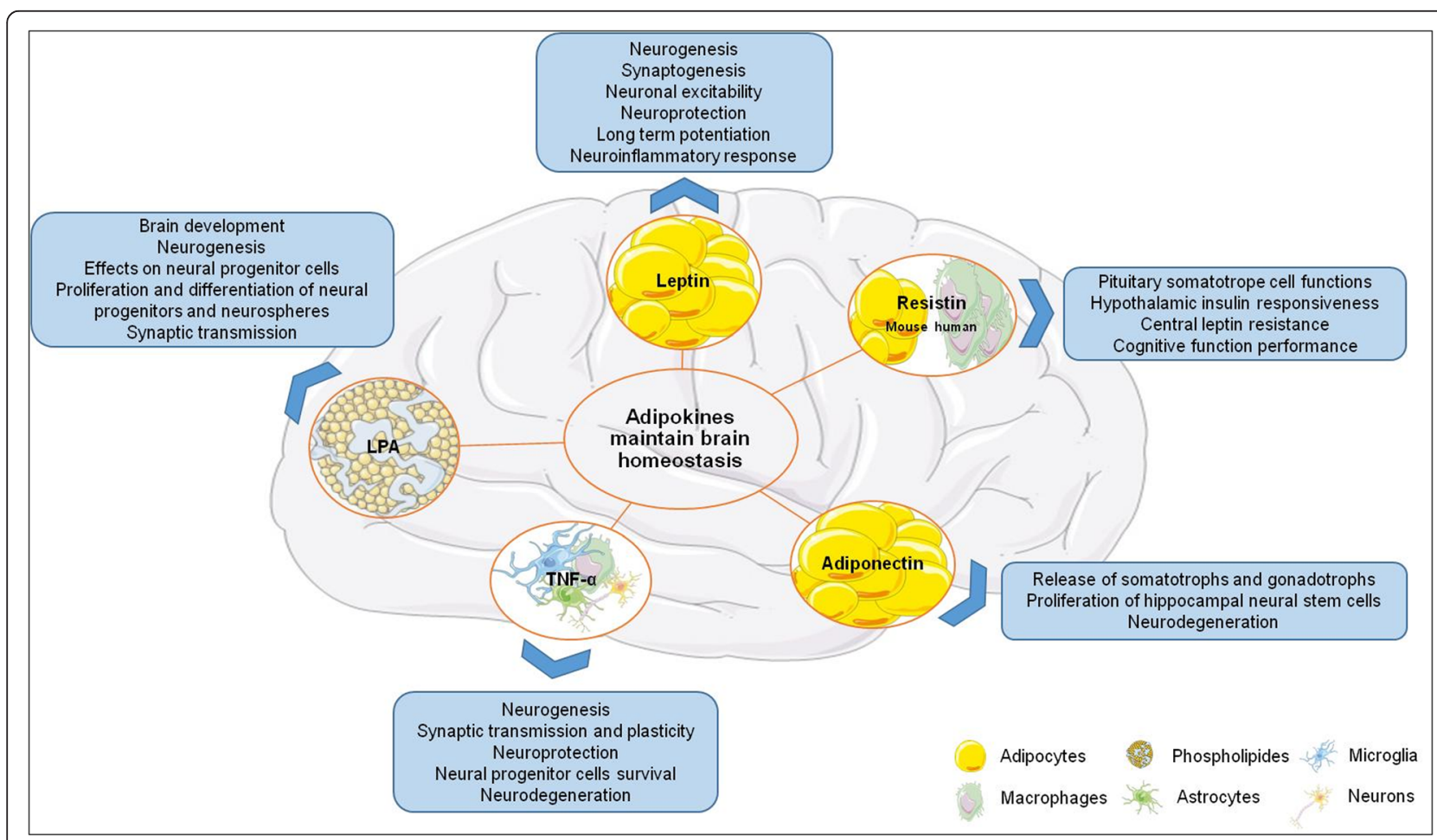

Fig. 1 Effects of the main adipokines on brain homeostasis/functions. LPA lisophosphatidic acid, TNFa tumor necrosis factor-a 
local functions for leptin than those previously described. Leptin receptors belong to the family of cytokine receptors, and at least five different isoforms have been identified in mouse: Ob-Ra to Ob-Re [65, 74]. In the CNS, leptin receptors (Ob-R or LepR) were first identified in choroid plexus and in the hypothalamus [75, 76]. Among all $\mathrm{Ob}-\mathrm{R}$ isoforms, only the full-length isoform (Ob-Rb) appears to fully transduce the activation signal at least in the brain and is essential for leptin's weight-reducing effects $[65,74]$. Ob-Rb is expressed in the hypothalamic nuclei notably in the arcuate nucleus (ARC), the dorsomedial nucleus $(\mathrm{DMH})$, the paraventricular nucleus (PVN), the ventromedial hypothalamic nucleus $(\mathrm{VMH})$, and the lateral hypothalamic nucleus (LH) $[65,77,78]$ but is also detected in the neocortex, the hippocampus, the hindbrain (nucleus of the solitary tract), the ventral tegmental area, the medulla, and the cerebellum [77, 79-83]. In addition, a weaker expression was also detected by in situ hybridization in the hippocampus and the thalamus [77]. The expression of leptin receptors and leptin mRNAs is documented in the mouse brain and notably in the main neurogenic niches, the subventricular zone of the lateral ventricles, and the dentate gyrus of the hippocampus (Allen Brain Atlas [http://www.brain-map.org], [84]). This work clearly illustrates the expression of leptin receptors in the cortex, along the ventricular walls and also in the hippocampus. Leptin is expressed in the same regions at lower levels. In the hypothalamus, the primary leptin targets are the orexigenic agouti-related peptide (AgRP) neurons and the anorexigenic pro-opiomelanocortin (POMC) neurons that are involved in feeding behavior. Thus, in the CNS, leptin activates anorexigenic POMC neurons through a neural network in the arcuate nucleus [85]. The appetite-stimulating effects of AgRP/NPY are inhibited by leptin in the arcuate nucleus avoiding the release of orexigenic factors [86, 87]. Furthermore, leptin receptors were also expressed in glutamatergic and GABAergic neurons [78, 88, 89]. Vong and colleagues (2011) have shown that the main effects of leptin are mediated by GABAergic neurons and only barely by glutamatergic neurons [88]. However, it was recently demonstrated that glutamate release mediates leptin action on energy expenditure [89]. We realize now that the effects of leptin on these different neuronal types and brain nuclei are not so easy to understand as originally thought. In homeostatic conditions, leptin inhibits food intake, and in extra-hypothalamic sites, leptin acts on neurogenesis, synaptogenesis, neuronal excitability, and neuroprotection $[9,90,91]$. Leptin was also shown to improve cognition and mood in depressed and anxious animal models, notably by improving long-term potentiation [9]. Leptin levels negatively correlated with the development of Alzheimer's disease in lean humans [91, 92], and leptin signaling seems to be dysregulated in Alzheimer's disease brains [93]. Interestingly, there are also positive correlations between plasma levels of leptin and body weight [94, 95].

\section{Resistin}

Resistin (or adipose tissue-specific secretory factor: ADSF or C/EBP-epsilon-regulated myeloid-specific secreted cysteine-rich protein: $\mathrm{XCP} 1$ ) is a cysteine-rich adipose-derived peptide hormone, encoded by the RETN gene, and known for its implication in inflammatory processes $[20,96]$. Its expression increases in parallel to adiposity [97-99] and is strongly related to insulin resistance in obese rodents [100]. Interestingly, in humans, resistin is mainly expressed and secreted by macrophages while adipocytes are the main source in rodents [100]. Resistin is known to play a key role in the CNS notably by regulating pituitary somatotrope cell functions [101], affecting hypothalamic and peripheral insulin responsiveness, thermogenesis, and feeding behavior, and also by enhancing renal sympathetic nerve activity [102-104]. However, the resistin receptor and the molecular mechanisms sustaining such effects are poorly understood and mainly unexplored until recently. Although resistin receptor has not been clearly identified, some potential candidate receptors have been proposed in different cell types such as an isoform of decorin (a small proteoglycan associated with collagen fibrils) in adipose progenitor cells, tyrosine kinase-like orphan receptor-1 (ROR1) in 3T3-L1 cells [105] or IGF-1R in fibroblast [106]. Nevertheless, it has been shown that resistin administration modulates or activates several signaling pathway involving Gs protein-dependent mechanisms, the adenylate cyclase/cAMP/protein kinase A pathway, the phosphatidylinositol 3-kinase/Akt pathway, the protein kinase $\mathrm{C}$, and extracellular $\mathrm{Ca}^{2+}$ signaling through L-type voltage-sensitive $\mathrm{Ca}^{2+}[102,107]$. Such puzzling data strongly suggest that resistin could potentially interact with different receptors depending on tissue and cell types. Furthermore, resistin also regulates the synthesis and secretion of the pro-inflammatory cytokines TNF $\alpha$ and IL-6 through nuclear factor-kBdependent pathway in macrophage [108-110]. Recently, Toll-like receptor 4 (TLR-4) receptors were identified as potential receptor for resistin in the hypothalamus, leading to the activation of JNK and p38/MAPK pathways [111]. Interestingly, resistin was also reported to be expressed in the hypothalamus and the cortex and to inactivate hypothalamic neurons [112-114]. In the rat brain, resistin is de novo produced suggesting specific roles for this local synthesis [114]. Resistin gene expression in the brain of mouse is reported in the cortex along the walls of the lateral ventricles and also in the hippocampus (Allen Brain Atlas [http://www.brainmap.org], [84]). In rat, traumatic brain injury (TBI) increased resistin mRNA expression in the ipsilateral 
cortex without any effects on the contralateral hemisphere. However, resistin expression is upregulated after TBI in the ipsi- and contralateral hippocampus [73]. One explanation is that given TBI compromises the integrity of the blood brain barrier, it could result in the changes in gene expression in the contralateral side of the hippocampus by exposing the brain to circulating factors of peripheral origin (Brown et al., 2008). The relatively rapid increase of resistin expression following TBI (at $12 \mathrm{~h}$ post-injury), is in contrast to the delayed upregulation of resistin in hypoxic ischemic mouse brain (>7 days) [115]. Thus, resistin could participate in the acute responses to cerebral damage probably through inflammatory mechanisms. A recent study suggested that resistin was not related to cognitive function performance [116].

\section{Adiponectin}

Adiponectin was first characterized in 1995 in 3T3-L1 adipocyte differentiation [117]. It is one of the most abundant adipokines considering its concentration in plasma relative to many other hormones $[118,119]$. Adiponectin self-associates into larger structures forming homotrimers that also self-associate and form hexamers or dodecamers. A globular fraction, named globular adiponectin, resulting from the cleavage of the full-length monomer, was also documented [120]. Adiponectin is mainly synthesized and secreted by adipocytes. However, it is now well admitted that adiponectin is expressed at the mRNA and/or protein level by the placenta, the liver, epithelial cells, osteoblasts, myocytes, and also by pituitary cells $[114,119,121]$. Interestingly, some studies documented adiponectin transcript expression in the diencephalon of chicken [114, 122] and in the human pituitary [121]. In the pituitary, adiponectin could have a role in the release of somatotrophs and gonadotrophs [119]. It also modulates a wide range of metabolic processes such as body-weight regulation, glucose regulation, insulin sensitivity, lipid catabolism (fatty acid oxidation), endothelial function, and also anti-atherogenic process $[119,123-126]$. Such effects are mediated by three different receptor types: adiponectin receptor 1 (AdipoR1), adiponectin receptor 2 (Adipo-R2), and T-cadherin (CDH13) and involved different signaling pathways including AMPK, p38-MAPK, JNK, PPAR- $\alpha$, and NF-kB. These receptors appear to be widely expressed in the mammalian brain including mouse, rat, pork and human. Their expression was documented in different brain structures such as the pituitary, the hypothalamus, and in cortical and subcortical neurons [97, 119, 121, 127-131]. In their review, Thundyil and colleagues (2012) documented adiponectin receptor expression in the central nervous system showing that Adipo-R1 is mainly expressed in the hypothalamus, the brainstem, and the pituitary gland while Adipo-R2 seems to be mostly expressed in the cortex. Furthermore, Adipo-R1 is strongly expressed in neurons and to a lesser extent in astrocytes while Adipo-R2 is figured to be only weakly expressed in astrocytes and neurons [119]. Adiponectin gene expression is widely expressed in the cortex and the hippocampus. Concerning T-cadherin receptor, it seems to be temporally and spatially expressed in different neuronal populations during axon growth [132]. Furthermore, T-cadherin showed broad expression in the cerebral cortex, basal ganglia, amygdala, and hippocampus in the developing postnatal telencephalon of marmoset (Callithrix jacchus) [133]. In mouse, CDH13 was also expressed by projection neurons within the main and accessory olfactory bulbs. Interestingly, adiponectin deficiency is associated with exaggerated inflammatory response in critical illness or septic patients [134-136]. Recently, Adipo-R1 and Adipo-R2 expression was described in both U373 MG (human glioblastoma astrocytoma cell line) and primary human astrocytes [137]. It also appears that adiponectin induces a pro-inflammatory response in human astrocytes, increasing notably IL-6 and MCP-1 through NF-kB, p38MAPK, and ERK1/2 pathways (Wan et al., 2014). In contrast, adiponectin was described to inhibit pro-inflammatory signal, notably by suppressing IL-6 release from blood brain barrier (BBB) endothelial cells [138]. It results that adiponectin indirectly modulates inflammatory signaling across the BBB by negatively modulating IL-6 and TNF $\alpha$ release. In vitro experiment of hippocampal neurons reveals that adiponectin exerts neuroprotective effects through AMPK pathway [139]. Such neuroprotective effects of adiponectin are further reinforced by the fact that knock-out mice for adiponectin exhibit more brain damages after ischemic stroke to controls [140]. This neuroprotective action is mediated through an endothelial nitric oxide synthase (eNOS)dependent mechanism [140].

\section{Tumor necrosis factor a}

Many pro-inflammatory factors are produced in activated WAT, such as TNF $\alpha$, IL-1, and PGE2. We choose to describe in more depth the prototype inflammatory cytokine TNF $\alpha$. TNF $\alpha$ is a pro-inflammatory adipokine well-known for its role in chronic peripheral and central inflammation $[9,141]$. TNF $\alpha$ is primarily produced as a transmembrane protein that self-associated into stable homotrimers [142, 143]. Such homotrimers could be cleaved by the TNF $\alpha$-converting enzyme (TACE, also called ADAM17), allowing the release of secreted form of TNF $\alpha$ [144]. In WAT, TNF $\alpha$ is produced by macrophages as well as by adipocytes, and its expression is increased at the mRNA and protein levels in obese and in T2DM models [145]. TNF $\alpha$ actions are mediated by two receptors: TNF-R1 (TNF-RSF1a) and TNF-R2 (TNFRSF1b). TNF-R1 is expressed in most tissues and can be 
fully activated by both the membrane-bound and soluble trimeric forms of TNF, while TNF-R2 is found in a limited cell types including cell of the immune system, oligodendrocytes, and certain neuron subtypes and responds to the membrane-bound form of the TNF homotrimer [9]. TNF-R1 and TNF-R2 are also expressed in the cortex, the subventricular zone of the lateral ventricle, and the hippocampus (Allen Brain Atlas [http://www.brain-map.org], [84]). In homeostatic conditions, the TNF $\alpha$ gene expression is low. However, in stress conditions (infection, trauma, pathologies), TNF $\alpha$ level can increase dramatically. As most information regarding TNF signaling is derived from TNF-R1, the role of TNF-R2 is likely underestimated. In rodents, TNF $\alpha$ has been shown to be transported across the BBB, but to be also locally produced by microglia, astrocytes and neurons in the brain [146-148]. In the CNS, TNF $\alpha$ acts through TNF-receptors on neurons and astrocytes regulating a wide range of cellular processes such as cell survival [9, 149, 150]. Actually, TNF $\alpha$ exhibits pleiotropic effects with positive and negative outcomes on the brain. On the one hand, TNF $\alpha$ is considered as the prototypic inflammatory cytokine and elevated levels of TNF have been described in many neurodegenerative situations [151, 152]. For instance, we have demonstrated the role of TNF in chemically induced neurodegeneration [153]. On the other hand, inhibition of TNF in inflammatory peripheral diseases induced CNS side effects including demyelination and neuropathies, suggesting a positive role for TNF maintaining the homeostasis in the CNS [154]. It acts on neurogenesis, synaptic transmission, and plasticity [9]. Thus, TNF $\alpha$ was described for its neuroprotective roles on hippocampal neurons by suppressing the accumulation of reactive oxygen species (ROS) and by maintaining intracellular levels of calcium [155]. In addition, it modulates glutamatergic transmission [156]. Furthermore, TNF $\alpha$ favors neural progenitor cell survival by mediating anti-apoptotic signals via TNF-R2 [157]. In rat, TNF $\alpha$ appears to promote the survival of stroke-generated hippocampal and striatal neurons [158]. In addition, TNF $\alpha$ knock-out mice show cognitive impairment (i.e., significant poorer learning, retention, and spatial learning), suggesting a strong role for TNF $\alpha$ on these mechanisms [159]. However, TNF $\alpha$ also exhibits a dark face, as reported in numerous other studies. It is notably involved in myelin damages [160], in favoring glutamate excitotoxicity [161], in inhibition of long-term potentiation in Cornu Ammonis area 1 (CA1) and in the dentate gyrus of the rat hippocampus $[150,162,163]$ and in decreasing neurogenesis $[164,165]$.

Altogether, these data established that the role of TNF $\alpha$ is complex. TNF $\alpha$ could exhibit multiple faces exerting neuroprotective versus neurotoxic roles, proversus anti-neurogenic effects according to the conditions (concentrations, physiological, or pathological conditions...). Neuroinflammation and metabolic disorders such as obesity could act on these mechanisms through an excess of TNF $\alpha$ secretion.

\section{Lysophosphatidic acid}

Among the factors secreted by the adipose tissue, there are many lipids from the lipokine family such as prostaglandin E2 (PGE2), anandamide, and also lysophosphatidic acid (LPA). LPA is a bioactive signaling phospholipid acting on a wide range of biological processes including cell growth, migration, and morphology [166]. LPA is detected in several biological fluids and tissues including the brain [167]. It is synthesized from different enzymatic activities involving notably phospholipase A1 and A2, monoacylglycerol kinase, but the main enzyme leading to LPA synthesis is autotaxin [168]. Autotaxin is a multifunctional phosphodiesterase that converts lysophospholipids into LPA through its lysophospholipase D activity. To date, LPA effects are mediated through five $\mathrm{G}$ protein coupled receptors. However, additional receptors have been identified for their potential responsiveness to LPA [168-170]. Using knock-out mice for the five most known LPA receptors (LPA-R), it was shown that LPA plays key roles on inflammation [171], angiogenesis [172], reproduction [173-175], brain development, and neurogenesis [176, 177]. Indeed, LPA exerts pleomorphic effects on neural progenitor cells from cortex, and notably calcium-mediated conductance [178]. In the nervous system, neural progenitor cells, neurons, oligodendrocytes, Schwann cells, astrocytes, and microglia have been documented for expressing different subsets of LPA receptors [168]. It partially explains why LPA exerts a wide variety of effects on these different cell types. Thus, LPA can favor proliferation and differentiation of neural progenitor cells as shown by treatment on ex vivo embryonic brain slice cultures resulting in an increase cell survival and differentiation [179]. Furthermore, LPA has been shown to promote proliferation and differentiation in neurospheres [180, 181]. LPA also displays effect on cell morphology and neurite formation in both neural progenitor cells and neurons [168]. It exhibits both cell death and survival properties on neurons possibly due to differences in LPA concentration or signaling through different receptors [182-184]. For instance, it induces apoptosis and necrosis in hippocampal neurons [182]. LPA also exerts various effects on glial and microglial cells, by modulating intracellular calcium levels in oligodendrocytes, astrocytes, and microglia [168]. It notably favors astrocytes and microglia proliferation in vitro $[185,186]$. Overexpression of autotaxin in microglia and by consequences, increased levels of LPA, protects the cells from an oxidative stress by increasing the level of catalase [187] and decreases the inflammatory 
response at least partially through an upregulation of IL10 [188]. Interestingly, following brain injury, in human postmortem brains, LPA receptors 1-3 and autotaxin are only weakly expressed while LPA-R2 is increased and autotaxin transcripts are decreased. Such data also reinforce the fact that LPA signaling is involved in neurotrauma [189]. During embryogenesis, LPA-R1 was detected in neural progenitors reinforcing a potential role of LPA/LPA-R1 signaling in neurogenesis [190]. In addition, LPAR-1 knock-out reduces brain cell proliferation, differentiation, and cell survival in the mouse dentate gyrus, consequently strongly impairing neurogenesis [176]. Autotaxin is widely expressed in the brain of mouse notably in neurogenic niches while LPA-R1 displays a lower and more discrete expression (Allen Brain Atlas [http:// www.brain-map.org], [84]).

\section{Blood brain barrier, adipokines, inflammation, and oxidative stress}

The effects and actions of adipokines on the CNS are dependent on their capacity to interact with the cells of the $\mathrm{BBB}$ and eventually to enter the CNS (Fig. 2). As mentioned above about the TNF $\alpha$, some adipokines including leptin can cross the BBB [9]. Concerning adiponectin, its capacity to cross the BBB is questionable. In one study, the results based on the measurement of radioactive labeled adiponectin and concentration in the cerebrospinal fluid indicate that adiponectin does not cross the BBB but will affect the cells of the BBB and indirectly affect the CNS acting via AMPK pathway $[9,138]$. In another work using adiponectin $\mathrm{KO}$ mice and recombinant adiponectin, it is shown that adiponectin crosses the BBB [191]. As the conclusion, these two publications proposed opposite results concerning the possibility of adiponectin to cross the $\mathrm{BBB}$, and more conclusive results will be needed to clarify this point.

The $\mathrm{BBB}$ is a key player in the adipokine signaling from the periphery to the CNS. Inflammation and oxidative stress associated with pathologies impact neurodegeneration and neurogenesis but also affect the BBB.

In this review, we highlighted the striking correlations between metabolic syndrome and the prevalence of neurological disorders and dementia including AD. White adipose tissue was not initially envisioned as a source of inflammatory factors. However, it is now well accepted that WAT is a key player in the development of a chronic low-grade inflammation associated with adiposity and consequently obesity $[192,193]$ with elevated production of pro-inflammatory cytokines, such as TNF $\alpha$, IL-6, and IL-1 [194, 195]. In contrast, loss of WAT is associated with a decrease in inflammation markers [196, 197]. Interestingly, chronic and low-grade inflammation has been proposed to negatively favor neurodegenerative diseases through the disruption of the BBB. Indeed, the blood brain barrier is a key interface linking systemic inflammation, neuroinflammation, and neurodegeneration [198], inflammatory factors being a main cause of the BBB disruption [199]. For instance, studies established positive correlations between mid-life adiposity in women with disruption of $\mathrm{BBB}$ integrity, showing that overweight/obesity could favor the onset of vascular disorders increasing BBB permeability later in life [200]. In the same line of evidence, rats fed with Western diet, known for promoting diabetes and obesity, display a leakier BBB due to the decreased expression of tight junctions [201]. Kanoski and colleagues have also shown that a primary cerebral target following BBB disruption is the hippocampus, well-known for its involvement in cognitive processes [201]. This is of peculiar interest given that $\mathrm{AD}$ patients display hippocampal atrophy and disruption of fronto-hippocampal connections early in the course of the disease [202-204]. This is further reinforced by the fact that $\mathrm{AD}$ in human and rodent models is strongly linked to an increased permeability of the BBB $[205,206]$. Consequently, the chronic low-grade inflammation that takes place in obese and diabetic people could negatively favor brain inflammation and degeneration through $\mathrm{BBB}$ disruption.

Some interesting links exist between dietary factors displaying anti-inflammatory properties, inflammation, and disease outcomes. For instance, polyphenols such as flavonoids and curcumin and spices such as cinnamon have been suggested to decrease pro-inflammatory cytokines, inflammation, and cardiovascular diseases and type 2 diabetes which are known to be risk factors for $\mathrm{AD}$ (for a recent review on this topic see ref [207]).

\section{Conclusions}

While the causal nature of all the processes leading to neurodegeneration has not been definitively established, it is widely accepted that neuroinflammation and oxidative stress responses occur with clinical manifestation of the disease. In this review, we described the impact of proinflammatory adipokines (TNF $\alpha$ and leptin) on brain homeostasis and functions. In addition, pro-inflammatory adipokines play a major role in the production of reactive oxygen species (ROS) [208, 209]. Due to its ability to secrete adipokines that promote ROS production, WAT has been regarded as an independent factor provoking oxidative stress [210-212]. Exposure to obesity for a long time in a host system downregulates and depletes the activity of antioxidant enzymes such as superoxide dismutase (SOD), catalase (CAT), and glutathione peroxidase (GPx); these enzymes being found to be significantly lowered compared with healthy persons which in turn lead to the development of obesity-related health problems [213]. In addition to this, levels of vitamin A and levels of serum antioxidants, such as vitamin $\mathrm{E}$, vitamin $\mathrm{C}$, and $\beta$-carotene, as well as glutathione, are also decreased 

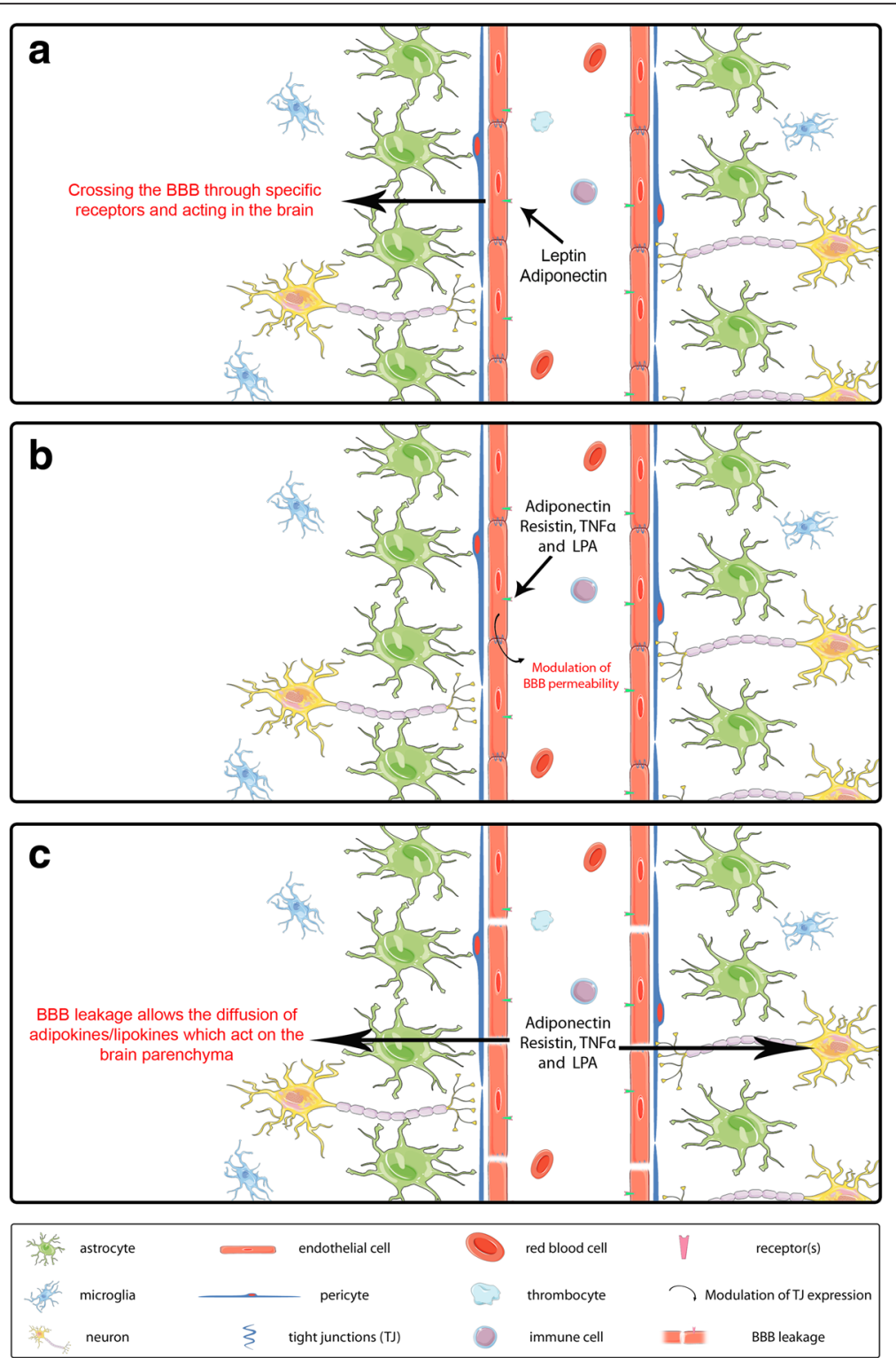

Fig. 2 Adipokines and LPA interactions with the blood brain barrier and the central nervous system. The BBB is composed of endothelial cells (displaying tight junctions), pericytes and astrocytes. a In physiological conditions, some adipokines such as leptin and TNFa can cross the BBB through different mechanisms and act on the central nervous system. b Adipokines can also activate endothelial cell receptors resulting in the modulation of the expression of tight junctions and in the modulation of the BBB permeability. In adiponectin case, one study reports its crossing through the BBB [191], while another indicates that it does not cross the BBB [138]. Both possibilities are shown. In inflammatory conditions, the BBB is leaking and could allow an increase passage of adipokines and LPA into the CNS, leading to an increase of oxidative stress and neurodegeneration (c)

in obesity [214]. When compared to the normal or lean individuals, obese individuals exhibit high levels of biomarkers of oxidative damage and inflammation such as C-reactive protein, LDL oxidation, and triglyceride levels [215]. Thus, apart from inflammation, which is quite wellknown to be one of the critical factors that damages the brain, ROS production which exceeds the antioxidant defenses in the host system is another factor that can also result in brain damages [216]. Cytokines produced by the monocytes and macrophages in WAT are the potent stimulators for the production of reactive oxygen (ROS) and nitrogen species (RNS) which generates oxidative stress. Adipose tissue also has the secretory capacity of angiotensin II, which stimulates nicotinamide adenine dinucleotide phosphate (NADPH) oxidase activity. NADPH oxidase comprises the major route for ROS production in adipocytes [217]). Thus, obesity results in an increased oxidative stress status that can lead to neural dysfunction and death 
$[218,219]$. It has been reported that obesity may induce systemic oxidative stress and, in turn, oxidative stress is associated with an irregular production of adipokines, which contributes to the development of the metabolic syndrome [220]. In parallel, oxidative stress is implicated in numerous neurological diseases and/or disorders such as $\mathrm{AD}, \mathrm{PD}$, amyotrophic lateral sclerosis (ALS), multiple sclerosis (MS), cerebral ischemia/reperfusion injury, and TBI, promoting neurodegeneration [221]. An increasing number of studies using in vitro models and knock-out animals demonstrate that oxidative stress disrupts the BBB permeability [221-223].

Taken together, these data suggest that in pathological conditions, adipokines released by WAT promote inflammation and ROS production that may disrupt the BBB permeability and could directly or indirectly act on different brain structures, the hippocampus being one of the most sensitive areas. It could explain why metabolic syndrome is associated with hippocampus atrophy and an increase risk to develop dementia such as AD. One main issue in people suffering from metabolic syndrome should be to struggle against inflammation and reduce oxidative stress in order to decrease their potential effects on brain neurodegeneration and their adverse effects.

\section{Competing interests}

The authors declare that they have no competing interests.

\section{Authors' contributions}

$\mathrm{CLH}$ and ND contributed equally to this work. AP carried out the writing of the study. ACD and ND contributed to the figures. CLH conceived the study. $\mathrm{CLH}$ and ND participated in its coordination and helped to draft the manuscript. AP, ACD, RA, RP, ND, and CLH contributed to the revision and edition of the study. All authors read and approved the final manuscript.

\section{Funding}

This work was supported by the grants from Conseil Régional de La Réunion and Europe (CPER/FEDER). ACD is funded by a fellowship from University of La Réunion. AP was funded by a fellowship from "Conseil Régional de La Réunion."

\section{Author details}

${ }^{1}$ Université de La Réunion, UMR 1188, Sainte-Clotilde F-97490, France. ${ }^{2}$ Inserm, UMR 1188 Diabète athérothrombose Thérapies Réunion Océan Indien (DéTROI), plateforme CYROI, Sainte-Clotilde F-97490, France. ${ }^{3}$ Lebanese University, Faculty of Sciences, Beirut, Lebanon. ${ }^{4}$ Apoptosis and Cell Death Research Lab, School of Biosciences and Technology, Vellore Institute of Technology University, Vellore, India.

Received: 7 December 2015 Accepted: 15 March 2016 Published online: 24 March 2016

\section{References}

1. Awada R, Parimisetty A, Lefebvre d'Hellencourt C. Influence of obesity on neurodegenerative diseases. Neurodegener Dis. 2013;Chapter 16:381-401.

2. World Health Organisation W: obesity and overweight. http://www.who.int/ mediacentre/factsheets/fs311/en/. Accessed 22 Mar 2016.

3. World Health Organisation W: diabetes. http://www.who.int/mediacentre/ factsheets/fs312/en/. Accessed 22 Mar 2016.

4. Alberti KG, Zimmet PZ. Definition, diagnosis and classification of diabetes mellitus and its complications. Part 1: diagnosis and classification of diabetes mellitus provisional report of a WHO consultation. Diabet Med. 1998;15:539-53.
5. Roglic G, Unwin N, Bennett PH, Mathers C, Tuomilehto J, Nag S, et al. The burden of mortality attributable to diabetes: realistic estimates for the year 2000. Diabetes Care. 2005;28:2130-5.

6. Reisberg B, Burns A, Brodaty H, Eastwood R, Rossor M, Sartorius N, et al. Diagnosis of Alzheimer's disease. Report of an International Psychogeriatric Association Special Meeting Work Group under the cosponsorship of Alzheimer's Disease International, the European Federation of Neurological Societies, the World Health Organization, and the World Psychiatric Association. Int Psychogeriatr. 1997;9 Suppl 1: $11-38$.

7. World Health Organisation W: dementia. http://www.who.int/mediacentre/ factsheets/fs362/en/. Accessed 22 Mar 2016.

8. Nguyen S, Major K, Demonet JF, Smith C, Rubli E, Humbert M, et al. [Diabetes and dementia: the dangerous liaisons?]. Rev Med Suisse. 2014; 2090-2092(10):2094-6.

9. Arnoldussen IA, Kiliaan AJ, Gustafson DR. Obesity and dementia: adipokines interact with the brain. Eur Neuropsychopharmacol. 2014;24:1982-1999.

10. Kiliaan AJ, Arnoldussen IA, Gustafson DR. Adipokines: a link between obesity and dementia? Lancet Neurol. 2014:13:913-23.

11. Gustafson DR, Backman K, Waern M, Ostling S, Guo X, Zandi P, et al. Adiposity indicators and dementia over 32 years in Sweden. Neurology. 2009;73:1559-66.

12. Letra L, Santana I, Seica R. Obesity as a risk factor for Alzheimer's disease: the role of adipocytokines. Metab Brain Dis. 2014;29:563-8.

13. Beydoun MA, Beydoun HA, Wang Y. Obesity and central obesity as risk factors for incident dementia and its subtypes: a systematic review and meta-analysis. Obes Rev. 2008;9:204-18.

14. Whitmer RA, Gustafson DR, Barrett-Connor E, Haan MN, Gunderson EP, Yaffe K. Central obesity and increased risk of dementia more than three decades later. Neurology. 2008;71:1057-64.

15. Qizilbash N, Gregson J, Johnson ME, Pearce N, Douglas I, Wing K, et al. BMl and risk of dementia in two million people over two decades: a retrospective cohort study. Lancet Diabetes Endocrinol. 2015;3:431-6.

16. Tolppanen AM, Ngandu T, Kareholt I, Laatikainen T, Rusanen M, Soininen $\mathrm{H}$, et al. Midlife and late-life body mass index and late-life dementia: results from a prospective population-based cohort. J Alzheimers Dis. 2014;38:201-9.

17. Adamczak M, Wiecek A. The adipose tissue as an endocrine organ. Semin Nephrol. 2013:33:2-13.

18. Lehr S, Hartwig S, Sell H. Adipokines: a treasure trove for the discovery of biomarkers for metabolic disorders. Proteomics Clin Appl. 2012;6:91-101.

19. Chaldakov GN. The adipobiology of disease. In: Immunology, endocrine \& metabolic agents in medicinal chemistry (formerly current medicinal chemistry_immunology, endocrine and metabolic agents), vol. Volume 7 , Number 2, April 2007. 2007. p. 105-5.

20. Ouchi N, Parker JL, Lugus JJ, Walsh K. Adipokines in inflammation and metabolic disease. Nat Rev Immunol. 2011;11:85-97.

21. Trayhurn P, Wood IS. Adipokines: inflammation and the pleiotropic role of white adipose tissue. Br J Nutr. 2004;92:347-55.

22. Maeda N, Shimomura I, Kishida K, Nishizawa H, Matsuda M, Nagaretani H, et al. Diet-induced insulin resistance in mice lacking adiponectin/ACRP30. Nat Med. 2002;8:731-7.

23. Xu A, Wang Y, Keshaw H, Xu LY, Lam KS, Cooper GJ. The fat-derived hormone adiponectin alleviates alcoholic and nonalcoholic fatty liver diseases in mice. J Clin Invest. 2003;112:91-100.

24. Trayhurn P, Beattie $\mathrm{JH}$. Physiological role of adipose tissue: white adipose tissue as an endocrine and secretory organ. Proc Nutr Soc. 2001;60:329-39.

25. Leal Vde O, Mafra D. Adipokines in obesity. Clin Chim Acta. 2013;419:87-94.

26. Ahima RS, Saper CB, Flier JS, Elmquist JK. Leptin regulation of neuroendocrine systems. Front Neuroendocrinol. 2000;21:263-307.

27. Bluher M, Mantzoros CS. From leptin to other adipokines in health and disease: facts and expectations at the beginning of the 21st century. Metabolism. 2015;64:131-45.

28. Bluher M. Adipokines-removing road blocks to obesity and diabetes therapy. Mol Metab. 2014;3:230-40.

29. Maury E, Brichard SM. Adipokine dysregulation, adipose tissue inflammation and metabolic syndrome. Mol Cell Endocrinol. 2010;314:1-16.

30. Ku IA, Farzaneh-Far R, Vittinghoff E, Zhang MH, Na B, Whooley MA. Association of low leptin with cardiovascular events and mortality in patients with stable coronary artery disease: the Heart and Soul Study. Atherosclerosis. 2011;217:503-8. 
31. Spranger J, Kroke A, Mohlig M, Bergmann MM, Ristow M, Boeing $H$, et al. Adiponectin and protection against type 2 diabetes mellitus. Lancet. 2003;361:226-8.

32. Herder C, Baumert J, Thorand B, Koenig W, de Jager W, Meisinger C, et al. Chemokines as risk factors for type 2 diabetes: results from the MONICA/ KORA Augsburg study, 1984-2002. Diabetologia. 2006:49:921-9.

33. Lee EB. Obesity, leptin, and Alzheimer's disease. Ann N Y Acad Sci. 2011;1243:15-29.

34. Gustafson D. Adiposity indices and dementia. Lancet Neurol. 2006;5:713-20.

35. Zhang P, Tian B. Metabolic syndrome: an important risk factor for Parkinson's disease. Oxid Med Cell Longev. 2014;2014:729194.

36. Gianfrancesco MA, Acuna B, Shen L, Briggs FB, Quach H, Bellesis KH, et al. Obesity during childhood and adolescence increases susceptibility to multiple sclerosis after accounting for established genetic and environmental risk factors. Obes Res Clin Pract. 2014;8:e435-47.

37. Versini M, Jeandel PY, Rosenthal E, Shoenfeld Y. Obesity in autoimmune diseases: not a passive bystander. Autoimmun Rev. 2014;13:981-1000.

38. Gustafson D, Rothenberg E, Blennow K, Steen B, Skoog I. An 18-year follow-up of overweight and risk of Alzheimer disease. Arch Intern Med. 2003;163:1524-8.

39. Nguyen JC, Killcross AS, Jenkins TA. Obesity and cognitive decline: role of inflammation and vascular changes. Front Neurosci. 2014;8:375.

40. Bruce-Keller AJ, Keller JN, Morrison CD. Obesity and vulnerability of the CNS. Biochim Biophys Acta. 1792;2009:395-400.

41. Taki Y, Kinomura S, Sato K, Inoue K, Goto R, Okada K, et al. Relationship between body mass index and gray matter volume in 1,428 healthy individuals. Obesity (Silver Spring). 2008;16:119-24.

42. Ward MA, Carlsson CM, Trivedi MA, Sager MA, Johnson SC. The effect of body mass index on global brain volume in middle-aged adults: a cross sectional study. BMC Neurol. 2005;5:23.

43. Debette S, Beiser A, Hoffmann U, Decarli C, O'Donnell CJ, Massaro JM, et al. Visceral fat is associated with lower brain volume in healthy middle-aged adults. Ann Neurol. 2010;68:136-44.

44. Gustafson D, Lissner L, Bengtsson C, Bjorkelund C, Skoog I. A 24-year follow-up of body mass index and cerebral atrophy. Neurology. 2004;63:1876-81.

45. Raji CA, Ho AJ, Parikshak NN, Becker JT, Lopez OL, Kuller LH, et al. Brain structure and obesity. Hum Brain Mapp. 2010;31:353-64.

46. Ho AJ, Stein JL, Hua X, Lee S, Hibar DP, Leow AD, et al. A commonly carried allele of the obesity-related FTO gene is associated with reduced brain volume in the healthy elderly. Proc Natl Acad Sci U S A. 2010;107:8404-9.

47. Cournot M, Marquie JC, Ansiau D, Martinaud C, Fonds H, Ferrieres J, et al. Relation between body mass index and cognitive function in healthy middle-aged men and women. Neurology. 2006;67:1208-14.

48. Lokken KL, Boeka AG, Austin HM, Gunstad J, Harmon CM. Evidence of executive dysfunction in extremely obese adolescents: a pilot study. Surg Obes Relat Dis. 2009;5:547-52.

49. Sabia S, Kivimaki M, Shipley MJ, Marmot MG, Singh-Manoux A. Body mass index over the adult life course and cognition in late midlife: the Whitehal II cohort study. Am J Clin Nutr. 2009;89:601-7.

50. McNeilly AD, Williamson R, Sutherland C, Balfour DJ, Stewart CA. High fat feeding promotes simultaneous decline in insulin sensitivity and cognitive performance in a delayed matching and non-matching to position task. Behav Brain Res. 2011;217:134-41.

51. Murray AJ, Knight NS, Cochlin LE, McAleese S, Deacon RM, Rawlins JN, et al. Deterioration of physical performance and cognitive function in rats with short-term high-fat feeding. FASEB J. 2009;23:4353-60.

52. Morris MJ, Beilharz JE, Maniam J, Reichelt AC, Westbrook RF. Why is obesity such a problem in the 21 st century? The intersection of palatable food, cues and reward pathways, stress, and cognition. Neurosci Biobehav Rev. 2015;58:36-45

53. Lynch CM, Kinzenbaw DA, Chen X, Zhan S, Mezzetti E, Filosa J, et al. Nox2-derived superoxide contributes to cerebral vascular dysfunction in diet-induced obesity. Stroke. 2013;44:3195-201.

54. Li W, Prakash R, Chawla D, Du W, Didion SP, Filosa JA, et al. Early effects of high-fat diet on neurovascular function and focal ischemic brain injury. Am J Physiol Regul Integr Comp Physiol. 2013;304:R1001-8.

55. Zhou H, Liu J, Ren L, Liu W, Xing Q, Men L, et al. Relationship between [corrected] spatial memory in diabetic rats and protein kinase Cgamma, caveolin-1 in the hippocampus and neuroprotective effect of catalpol. Chin Med J (Engl). 2014;127:916-23.
56. McCrimmon RJ, Ryan CM, Frier BM. Diabetes and cognitive dysfunction. Lancet. 2012;379:2291-9.

57. Zhang YW, Zhang JQ, Liu C, Wei P, Zhang X, Yuan QY, et al. Memory dysfunction in type 2 diabetes mellitus correlates with reduced hippocampal CA1 and subiculum volumes. Chin Med J (Engl). 2015;128:465-71.

58. Biessels GJ, Deary IJ, Ryan CM. Cognition and diabetes: a lifespan perspective. Lancet Neurol. 2008;7:184-90.

59. Haan MN. Therapy insight: type 2 diabetes mellitus and the risk of late-onset Alzheimer's disease. Nat Clin Pract Neurol. 2006;2:159-66.

60. Cheng $G$, Huang $C$, Deng $H$, Wang $H$. Diabetes as a risk factor for dementia and mild cognitive impairment: a meta-analysis of longitudinal studies. Intern Med J. 2012;42:484-91.

61. Whitmer RA. Type 2 diabetes and risk of cognitive impairment and dementia. Curr Neurol Neurosci Rep. 2007;7:373-80.

62. Macknight C, Rockwood K, Awalt E, McDowell I. Diabetes mellitus and the risk of dementia, Alzheimer's disease and vascular cognitive impairment in the Canadian Study of Health and Aging. Dement Geriatr Cogn Disord. 2002;14:77-83.

63. Ho N, Sommers MS, Lucki I. Effects of diabetes on hippocampal neurogenesis: links to cognition and depression. Neurosci Biobehav Rev. 2013;37:1346-62.

64. Zhang $Y$, Proenca R, Maffei M, Barone M, Leopold L, Friedman JM. Positional cloning of the mouse obese gene and its human homologue. Nature. 1994;372:425-32.

65. Friedman JM, Halaas JL. Leptin and the regulation of body weight in mammals. Nature. 1998;395:763-70.

66. Banks WA, Kastin AJ, Huang W, Jaspan JB, Maness LM. Leptin enters the brain by a saturable system independent of insulin. Peptides. 1996;17:305-11.

67. Banks WA, Clever CM, Farrell CL. Partial saturation and regional variation in the blood-to-brain transport of leptin in normal weight mice. Am J Physiol Endocrinol Metab. 2000;278:E1158-65.

68. Devos R, Richards JG, Campfield LA, Tartaglia LA, Guisez Y, van der Heyden J, et al. OB protein binds specifically to the choroid plexus of mice and rats. Proc Natl Acad Sci U S A. 1996;93:5668-73.

69. Zlokovic BV, Jovanovic S, Miao W, Samara S, Verma S, Farrell CL. Differential regulation of leptin transport by the choroid plexus and blood-brain barrier and high affinity transport systems for entry into hypothalamus and across the blood-cerebrospinal fluid barrier. Endocrinology. 2000;141:1434-41.

70. Wilkinson M, Morash B, Ur E. The brain is a source of leptin. Front Horm Res. 2000;26:106-25.

71. Morash B, Li A, Murphy PR, Wilkinson M, Ur E. Leptin gene expression in the brain and pituitary gland. Endocrinology. 1999;140:5995-8.

72. Brown R, Imran SA, Belsham DD, Ur E, Wilkinson M. Adipokine gene expression in a novel hypothalamic neuronal cell line: resistin-dependent regulation of fasting-induced adipose factor and SOCS-3. Neuroendocrinology. 2007:85:232-41.

73. Brown R, Thompson HJ, Imran SA, Ur E, Wilkinson M. Traumatic brain injury induces adipokine gene expression in rat brain. Neurosci Lett. 2008;432:73-8.

74. Gorska E, Popko K, Stelmaszczyk-Emmel A, Ciepiela O, Kucharska A, Wasik M. Leptin receptors. Eur J Med Res. 2010;15 Suppl 2:50-4.

75. Tartaglia LA. The leptin receptor. J Biol Chem. 1997;272:6093-6.

76. Tartaglia LA, Dembski M, Weng X, Deng N, Culpepper J, Devos R, et al. Identification and expression cloning of a leptin receptor, OB-R. Cell. 1995:83:1263-71.

77. Mercer JG, Hoggard N, Williams LM, Lawrence CB, Hannah LT, Trayhurn P. Localization of leptin receptor mRNA and the long form splice variant (Ob-Rb) in mouse hypothalamus and adjacent brain regions by in situ hybridization. FEBS Lett. 1996;387:113-6.

78. Yi CX, Meyer CW, Jastroch M. Leptin action in the brain: How (and when) it makes fat burn. Mol Metab. 2013:2:63-4.

79. Burguera B, Couce ME, Long J, Lamsam J, Laakso K, Jensen MD, et al. The long form of the leptin receptor (OB-Rb) is widely expressed in the human brain. Neuroendocrinology. 2000;71:187-95.

80. Savioz A, Charnay Y, Huguenin C, Graviou C, Greggio B, Bouras C. Expression of leptin receptor mRNA (long form splice variant) in the human cerebellum. Neuroreport. 1997;8:3123-6.

81. Shanley $\sqcup$, O'Malley D, Irving AJ, Ashford ML, Harvey J. Leptin inhibits epileptiform-like activity in rat hippocampal neurones via PI 3-kinase-driven activation of BK channels. J Physiol. 2002;545:933-44.

82. Scott MM, Williams KW, Rossi J, Lee CE, Elmquist JK. Leptin receptor expression in hindbrain Glp-1 neurons regulates food intake and energy balance in mice. J Clin Invest. 2011;121:2413-21. 
83. Scott MM, Lachey JL, Sternson SM, Lee CE, Elias CF, Friedman JM, et al. Leptin targets in the mouse brain. J Comp Neurol. 2009;514:518-32.

84. Lein ES, Hawrylycz MJ, Ao N, Ayres M, Bensinger A, Bernard A, et al. Genome-wide atlas of gene expression in the adult mouse brain. Nature. 2007:445:168-76

85. Cowley MA, Smart JL, Rubinstein M, Cerdan MG, Diano S, Horvath TL, et al. Leptin activates anorexigenic POMC neurons through a neural network in the arcuate nucleus. Nature. 2001;411:480-4.

86. Baskin DG, Hahn TM, Schwartz MW. Leptin sensitive neurons in the hypothalamus. Horm Metab Res. 1999;31:345-50.

87. Enriori PJ, Evans AE, Sinnayah P, Jobst EE, Tonelli-Lemos L, Billes SK, et al. Diet-induced obesity causes severe but reversible leptin resistance in arcuate melanocortin neurons. Cell Metab. 2007;5:181-94.

88. Vong L, Ye C, Yang Z, Choi B, Chua Jr S, Lowell BB. Leptin action on GABAergic neurons prevents obesity and reduces inhibitory tone to POMC neurons. Neuron. 2011;71:142-54

89. Xu Y, Kim ER, Zhao R, Myers Jr MG, Munzberg H, Tong Q. Glutamate release mediates leptin action on energy expenditure. Mol Metab. 2013;2:109-15.

90. Bouret SG. Neurodevelopmental actions of leptin. Brain Res. 2010;1350:2-9

91. Paz-Filho G, Wong ML, Licinio J. The procognitive effects of leptin in the brain and their clinical implications. Int J Clin Pract. 2010;64:1808-12.

92. Paz-Filho G, Wong ML, Licinio J. Leptin levels and Alzheimer disease. JAMA. 2010;303:1478. author reply 1478-1479.

93. Bonda DJ, Stone JG, Torres SL, Siedlak SL, Perry G, Kryscio R, et al. Dysregulation of leptin signaling in Alzheimer disease: evidence for neuronal leptin resistance. J Neurochem. 2014;128:162-72.

94. Fleisch AF, Agarwal N, Roberts MD, Han JC, Theim KR, Vexler A, et al. Influence of serum leptin on weight and body fat growth in children at high risk for adult obesity. J Clin Endocrinol Metab. 2007;92:948-54.

95. Salbe AD, Weyer C, Lindsay RS, Ravussin E, Tataranni PA. Assessing risk factors for obesity between childhood and adolescence: I. Birth weight, childhood adiposity, parental obesity, insulin, and leptin. Pediatrics. 2002; 110:299-306.

96. Wang H, Chu WS, Hemphill C, Elbein SC. Human resistin gene: molecular scanning and evaluation of association with insulin sensitivity and type 2 diabetes in Caucasians. J Clin Endocrinol Metab. 2002;87:2520-4.

97. Degawa-Yamauchi M, Bovenkerk JE, Juliar BE, Watson W, Kerr K, Jones R, et al. Serum resistin (FIZZ3) protein is increased in obese humans. J Clin Endocrinol Metab. 2003:88:5452-5.

98. Lee JH, Bullen Jr JW, Stoyneva VL, Mantzoros CS. Circulating resistin in lean, obese, and insulin-resistant mouse models: lack of association with insulinemia and glycemia. Am J Physiol Endocrinol Metab. 2005; 288:E625-32.

99. Vendrell J, Broch M, Vilarrasa N, Molina A, Gomez JM, Gutierrez C, et al. Resistin, adiponectin, ghrelin, leptin, and proinflammatory cytokines: relationships in obesity. Obes Res. 2004;12:962-71.

100. Park HK, Ahima RS. Resistin in rodents and humans. Diabetes Metab J. 2013;37:404-14.

101. Broglio C, Gómez A, Durán E, Ocaña FM, Jiménez-Moya F, Rodríguez F, et al. Hallmarks of a common forebrain vertebrate plan: specialized pallial areas for spatial, temporal and emotional memory in actinopterygian fish. Brain Res Bull. 2005;66:277-81.

102. Kosari S, Camera DM, Hawley JA, Stebbing M, Badoer E. ERK1/2 in the brain mediates the effects of central resistin on reducing thermogenesis in brown adipose tissue. Int J Physiol Pathophysiol Pharmacol. 2013;5:184-9.

103. Kosari S, Rathner JA, Badoer E. Central resistin enhances renal sympathetic nerve activity via phosphatidylinositol 3-kinase but reduces the activity to brown adipose tissue via extracellular signal-regulated kinase 1/2. J Neuroendocrinol. 2012;24:1432-9.

104. Yi CX, Tschop MH. Brain-gut-adipose-tissue communication pathways at a glance. Dis Model Mech. 2012;5:583-7.

105. Sanchez-Solana B, Laborda J, Baladron V. Mouse resistin modulates adipogenesis and glucose uptake in 3T3-L1 preadipocytes through the ROR1 receptor. Mol Endocrinol. 2012;26:110-27.

106. Böstrom EA, Svensson M, Andersson S, Jonsson IM, Ekwall AK, Eisler T, et al. Resistin and insulin/insulin-like growth factor signaling in rheumatoid arthritis. Arthritis Rheum. 2011;63:2894-904.

107. Rodriguez-Pacheco F, Vazquez-Martinez R, Martinez-Fuentes AJ, Pulido MR, Gahete MD, Vaudry $H$, et al. Resistin regulates pituitary somatotrope cell function through the activation of multiple signaling pathways. Endocrinology. 2009;150:4643-52.

108. Bokarewa M, Nagaev I, Dahlberg L, Smith U, Tarkowski A. Resistin, an adipokine with potent proinflammatory properties. J Immunol. 2005; 174:5789-95

109. Olefsky JM, Glass CK. Macrophages, inflammation, and insulin resistance. Annu Rev Physiol. 2010;72:219-46.

110. Silswal N, Singh AK, Aruna B, Mukhopadhyay S, Ghosh S, Ehtesham NZ. Human resistin stimulates the pro-inflammatory cytokines TNF-alpha and IL-12 in macrophages by NF-kappaB-dependent pathway. Biochem Biophys Res Commun. 2005;334:1092-101.

111. Benomar Y, Gertler A, De Lacy P, Crepin D, Ould Hamouda H, Riffault L, et al. Central resistin overexposure induces insulin resistance through Toll-like receptor 4. Diabetes. 2013;62:102-14.

112. Brown $\mathrm{R}$, Wiesner $\mathrm{G}$, Ur E, Wilkinson M. Pituitary resistin gene expression is upregulated in vitro and in vivo by dexamethasone but is unaffected by rosiglitazone. Neuroendocrinology. 2005;81:41-8.

113. Morash BA, Willkinson D, Ur E, Wilkinson M. Resistin expression and regulation in mouse pituitary. FEBS Lett. 2002;526:26-30.

114. Wilkinson M, Brown R, Imran SA, Ur E. Adipokine gene expression in brain and pituitary gland. Neuroendocrinology. 2007;86:191-209.

115. Wiesner G, Brown RE, Robertson GS, Imran SA, Ur E, Wilkinson M. Increased expression of the adipokine genes resistin and fasting-induced adipose factor in hypoxic/ischaemic mouse brain. Neuroreport. 2006;17:1195-8.

116. Miralbell J, Lopez-Cancio E, Lopez-Oloriz J, Arenillas JF, Barrios M, Soriano-Raya JJ, et al. Cognitive patterns in relation to biomarkers of cerebrovascular disease and vascular risk factors. Cerebrovasc Dis. 2013; 36:98-105.

117. Scherer PE, Williams S, Fogliano M, Baldini G, Lodish HF. A novel serum protein similar to C1q, produced exclusively in adipocytes. J Biol Chem. 1995;270:26746-9

118. Matsuzawa Y. Adiponectin: identification, physiology and clinical relevance in metabolic and vascular disease. Atheroscler Suppl. 2005;6:7-14.

119. Thundyil J, Pavlovski D, Sobey CG, Arumugam TV. Adiponectin receptor signalling in the brain. Br J Pharmacol. 2012;165:313-27.

120. Waki H, Yamauchi T, Kamon J, Ito Y, Uchida S, Kita S, et al. Impaired multimerization of human adiponectin mutants associated with diabetes. Molecular structure and multimer formation of adiponectin. J Biol Chem. 2003;278:40352-63.

121. Psilopanagioti A, Papadaki H, Kranioti EF, Alexandrides TK, Varakis JN. Expression of adiponectin and adiponectin receptors in human pituitary gland and brain. Neuroendocrinology. 2009;89:38-47.

122. Maddineni S, Metzger S, Ocon O, Hendricks 3rd G, Ramachandran R. Adiponectin gene is expressed in multiple tissues in the chicken: food deprivation influences adiponectin messenger ribonucleic acid expression. Endocrinology. 2005;146:4250-6.

123. Berg AH, Combs TP, Scherer PE. ACRP30/adiponectin: an adipokine regulating glucose and lipid metabolism. Trends Endocrinol Metab. 2002;13:84-9.

124. Okamoto Y, Kihara S, Ouchi N, Nishida M, Arita Y, Kumada M, et al. Adiponectin reduces atherosclerosis in apolipoprotein E-deficient mice. Circulation. 2002;106:2767-70.

125. Stefan N, Stumvoll M. Adiponectin -its role in metabolism and beyond Horm Metab Res. 2002:34:469-74.

126. Whitehead JP, Richards AA, Hickman IJ, Macdonald GA, Prins JB. Adiponectin - a key adipokine in the metabolic syndrome. Diabetes Obes Metab. 2006;8:264-80

127. Fry M, Smith PM, Hoyda TD, Duncan M, Ahima RS, Sharkey KA, et al. Area postrema neurons are modulated by the adipocyte hormone adiponectin J Neurosci. 2006;26:9695-702.

128. Hoyda TD, Fry M, Ahima RS, Ferguson AV. Adiponectin selectively inhibits oxytocin neurons of the paraventricular nucleus of the hypothalamus. J Physiol. 2007:585:805-16.

129. Thundyil J, Tang SC, Okun E, Shah K, Karamyan VT, Li YI, et al. Evidence that adiponectin receptor 1 activation exacerbates ischemic neuronal death. Exp Transl Stroke Med. 2010;2:15

130. Repunte-Canonigo V, Berton F, Cottone P, Reifel-Miller A, Roberts AJ, Morales $\mathrm{M}$, et al. A potential role for adiponectin receptor 2 (AdipoR2) in the regulation of alcohol intake. Brain Res. 2010;1339:11-7.

131. Yamauchi T, Kamon J, Ito Y, Tsuchida A, Yokomizo T, Kita S, et al. Cloning of adiponectin receptors that mediate antidiabetic metabolic effects. Nature. 2003;423:762-9. 
132. Ranscht B, Dours-Zimmermann MT. T-cadherin, a novel cadherin cell adhesion molecule in the nervous system lacks the conserved cytoplasmic region. Neuron. 1991;7:391-402.

133. Matsunaga $E$, Nambu S, Oka M, Iriki A. Differential cadherin expression in the developing postnatal telencephalon of a New World monkey. J Comp Neurol. 2013;521:4027-60.

134. Venkatesh B, Hickman I, Nisbet J, Cohen J, Prins J. Changes in serum adiponectin concentrations in critical illness: a preliminary investigation. Crit Care. 2009;13:R105

135. Hillenbrand A, Knippschild $U$, Weiss $M$, Schrezenmeier $H$, Henne-Bruns D, Huber-Lang M, et al. Sepsis induced changes of adipokines and cytokines - septic patients compared to morbidly obese patients. BMC Surg. 2010;10:26.

136. Hillenbrand A, Weiss M, Knippschild U, Wolf AM, Huber-Lang M. Sepsis-induced adipokine change with regard to insulin resistance. Int J Inflam. 2012;2012:972368.

137. Wan Z, Mah D, Simtchouk S, Klegeris A, Little JP. Globular adiponectin induces a pro-inflammatory response in human astrocytic cells. Biochem Biophys Res Commun. 2014;446:37-42.

138. Spranger J, Verma S, Gohring I, Bobbert T, Seifert J, Sindler AL, et al. Adiponectin does not cross the blood-brain barrier but modifies cytokine expression of brain endothelial cells. Diabetes. 2006;55:141-7.

139. Qiu G, Wan R, Hu J, Mattson MP, Spangler E, Liu S, et al. Adiponectin protects rat hippocampal neurons against excitotoxicity. Age (Dordr). 2011;33:155-65.

140. Nishimura M, Izumiya Y, Higuchi A, Shibata R, Qiu J, Kudo C, et al. Adiponectin prevents cerebral ischemic injury through endothelial nitric oxide synthase dependent mechanisms. Circulation. 2008;117:216-23.

141. Thaler JP, Yi CX, Schur EA, Guyenet SJ, Hwang BH, Dietrich MO, et al. Obesity is associated with hypothalamic injury in rodents and humans. J Clin Invest. 2012;122:153-62.

142. Kriegler M, Perez C, DeFay K, Albert I, Lu SD. A novel form of TNF/cachectin is a cell surface cytotoxic transmembrane protein: ramifications for the complex physiology of TNF. Cell. 1988;53:45-53.

143. Tang P, Hung MC, Klostergaard J. TNF cytotoxicity: effects of HER-2/neu expression and inhibitors of ADP-ribosylation. Lymphokine Cytokine Res. 1994;13:117-23.

144. Black RA, Rauch CT, Kozlosky CJ, Peschon JJ, Slack JL, Wolfson MF, et al. A metalloproteinase disintegrin that releases tumour-necrosis factor-alpha from cells. Nature. 1997;385:729-33.

145. Hotamisligil GS, Shargill NS, Spiegelman BM. Adipose expression of tumor necrosis factor-alpha: direct role in obesity-linked insulin resistance. Science. 1993:259:87-91.

146. Morganti-Kossman MC, Lenzlinger PM, Hans V, Stahel P, Csuka E, Ammann

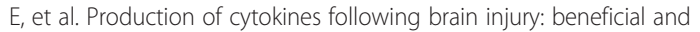
deleterious for the damaged tissue. Mol Psychiatry. 1997;2:133-6.

147. Chung IY, Benveniste EN. Tumor necrosis factor-alpha production by astrocytes. Induction by lipopolysaccharide, IFN-gamma, and IL-1 beta. J Immunol. 1990;144:2999-3007.

148. Lieberman AP, Pitha PM, Shin HS, Shin ML. Production of tumor necrosis factor and other cytokines by astrocytes stimulated with lipopolysaccharide or a neurotropic virus. Proc Natl Acad Sci U S A. 1989;86:6348-52.

149. Montgomery SL, Bowers WJ. Tumor necrosis factor-alpha and the roles it plays in homeostatic and degenerative processes within the central nervous system. J Neuroimmune Pharmacol. 2012;7:42-59.

150. Pickering M, Cumiskey D, O'Connor JJ. Actions of TNF-alpha on glutamatergic synaptic transmission in the central nervous system. Exp Physiol. 2005;90:663-70.

151. Clark IA, Vissel B. A neurologist's guide to TNF biology and to the principles behind the therapeutic removal of excess TNF in disease. Neural Plast. 2015; 2015:358263.

152. Fischer R, Maier O. Interrelation of oxidative stress and inflammation in neurodegenerative disease: role of TNF. Oxid Med Cell Longev. 2015; 2015:610813.

153. Harry GJ, Funk JA, Lefebvre d'Hellencourt C, McPherson CA, Aoyama M. The type 1 interleukin 1 receptor is not required for the death of murine hippocampal dentate granule cells and microglia activation. Brain Res. 2008;1194:8-20.

154. Probert L. TNF and its receptors in the CNS: the essential, the desirable and the deleterious effects. Neuroscience. 2015;302:2-22.

155. Barger SW, Horster D, Furukawa K, Goodman Y, Krieglstein J, Mattson MP. Tumor necrosis factors alpha and beta protect neurons against amyloid beta-peptide toxicity: evidence for involvement of a kappa B-binding factor and attenuation of peroxide and Ca2+ accumulation. Proc Natl Acad Sci U S A. 1995;92:9328-32.

156. Beattie EC, Stellwagen D, Morishita W, Bresnahan JC, Ha BK, Von Zastrow M, et al. Control of synaptic strength by glial TNFalpha. Science. 2002;295:2282-5.

157. Marchetti L, Klein M, Schlett K, Pfizenmaier K, Eisel UL. Tumor necrosis factor (TNF)-mediated neuroprotection against glutamate-induced excitotoxicity is enhanced by $\mathrm{N}$-methyl-D-aspartate receptor activation. Essential role of a TNF receptor 2-mediated phosphatidylinositol 3-kinase-dependent NF-kappa B pathway. J Biol Chem. 2004;279:32869-81.

158. Heldmann U, Thored P, Claasen JH, Arvidsson A, Kokaia Z, Lindvall O. TNF-alpha antibody infusion impairs survival of stroke-generated neuroblasts in adult rat brain. Exp Neurol. 2005;196:204-8.

159. Baune BT, Wiede F, Braun A, Golledge J, Arolt V, Koerner H. Cognitive dysfunction in mice deficient for TNF- and its receptors. Am J Med Genet B Neuropsychiatr Genet. 2008;147B:1056-64.

160. Selmaj K, Raine CS. Tumor necrosis factor mediates myelin damage in organotypic cultures of nervous tissue. Ann N Y Acad Sci. 1988;540:568-70.

161. Hermann GE, Rogers RC, Bresnahan JC, Beattie MS. Tumor necrosis factor-alpha induces CFOS and strongly potentiates glutamate-mediated cell death in the rat spinal cord. Neurobiol Dis. 2001;8:590-9.

162. Butler MP, O'Connor JJ, Moynagh PN. Dissection of tumor-necrosis factor-alpha inhibition of long-term potentiation (LTP) reveals a p38 mitogen-activated protein kinase-dependent mechanism which maps to early-but not late-phase LTP. Neuroscience. 2004:124:319-26.

163. Cunningham AJ, Murray CA, O'Neill LA, Lynch MA, O'Connor JJ. Interleukin-1 beta (IL-1 beta) and tumour necrosis factor (TNF) inhibit long-term potentiation in the rat dentate gyrus in vitro. Neurosci Lett. 1996;203:17-20.

164. Lan X, Chen Q, Wang Y, Jia B, Sun L, Zheng J, et al. TNF-alpha affects human cortical neural progenitor cell differentiation through the autocrine secretion of leukemia inhibitory factor. PLoS ONE. 2012;7:e50783.

165. losif RE, Ekdahl CT, Ahlenius H, Pronk CJ, Bonde S, Kokaia Z, et al. Tumor necrosis factor receptor 1 is a negative regulator of progenitor proliferation in adult hippocampal neurogenesis. J Neurosci. 2006;26:9703-12.

166. Frisca F, Sabbadini RA, Goldshmit Y, Pebay A. Biological effects of lysophosphatidic acid in the nervous system. Int Rev Cell Mol Biol. 2012;296:273-322

167. Tokumura A. Metabolic pathways and physiological and pathological significances of lysolipid phosphate mediators. J Cell Biochem. 2004 92:869-81.

168. Noguchi K, Herr D, Mutoh T, Chun J. Lysophosphatidic acid (LPA) and its receptors. Curr Opin Pharmacol. 2009:9:15-23.

169. Kotarsky K, Boketoft A, Bristulf J, Nilsson NE, Norberg A, Hansson S, et al. Lysophosphatidic acid binds to and activates GPR92, a G protein-coupled receptor highly expressed in gastrointestinal lymphocytes. J Pharmacol Exp Ther. 2006:318:619-28.

170. Noguchi K, Ishii S, Shimizu T. Identification of p2y9/GPR23 as a novel G protein-coupled receptor for lysophosphatidic acid, structurally distant from the Edg family. J Biol Chem. 2003;278:25600-6.

171. Zhao Y, Natarajan V. Lysophosphatidic acid (LPA) and its receptors: role in airway inflammation and remodeling. Biochim Biophys Acta. 1831;2013:86-92.

172. Chen Y, Ramakrishnan DP, Ren B. Regulation of angiogenesis by phospholipid lysophosphatidic acid. Front Biosci (Landmark Ed). 2013;18:852-61

173. Ye X, Skinner MK, Kennedy G, Chun J. Age-dependent loss of sperm production in mice via impaired lysophosphatidic acid signaling. Biol Reprod. 2008;79:328-36.

174. Ye X, Hama K, Contos JJ, Anliker B, Inoue A, Skinner MK, et al. LPA3-mediated lysophosphatidic acid signalling in embryo implantation and spacing. Nature 2005:435:104-8.

175. Ye X, Chun J. Lysophosphatidic acid (LPA) signaling in vertebrate reproduction. Trends Endocrinol Metab. 2010;21:17-24.

176. Matas-Rico E, Garcia-Diaz B, Llebrez-Zayas P, Lopez-Barroso D, Santin L, Pedraza C, et al. Deletion of lysophosphatidic acid receptor LPA1 reduces neurogenesis in the mouse dentate gyrus. Mol Cell Neurosci. 2008:39:342-55

177. Estivill-Torrus G, Llebrez-Zayas P, Matas-Rico E, Santin L, Pedraza C, De Diego l, et al. Absence of LPA1 signaling results in defective cortical development. Cereb Cortex. 2008;18:938-50. 
178. Dubin AE, Herr DR, Chun J. Diversity of lysophosphatidic acid receptor-mediated intracellular calcium signaling in early cortical neurogenesis. J Neurosci. 2010;30:7300-9.

179. Kingsbury MA, Rehen SK, Contos JJ, Higgins CM, Chun J. Non-proliferative effects of lysophosphatidic acid enhance cortical growth and folding. Nat Neurosci. 2003;6:1292-9.

180. Fukushima N, Shano S, Moriyama R, Chun J. Lysophosphatidic acid stimulates neuronal differentiation of cortical neuroblasts through the LPA1-G(i/O) pathway. Neurochem Int. 2007;50:302-7.

181. Svetlov SI, Ignatova TN, Wang KK, Hayes RL, English D, Kukekov VG. Lysophosphatidic acid induces clonal generation of mouse neurospheres via proliferation of Sca-1- and AC133-positive neural progenitors. Stem Cells Dev. 2004;13:685-93.

182. Holtsberg FW, Steiner MR, Keller JN, Mark RJ, Mattson MP, Steiner SM. Lysophosphatidic acid induces necrosis and apoptosis in hippocampal neurons. J Neurochem. 1998;70:66-76.

183. Zheng ZQ, Fang XJ, Zhang Y, Qiao JT. Neuroprotective effect of lysophosphatidic acid on AbetaP31-35-induced apoptosis in cultured cortical neurons. Sheng Li Xue Bao. 2005;57:289-94.

184. Zheng ZQ, Fang XJ, Qiao JT. Dual action of lysophosphatidic acid in cultured cortical neurons: survival and apoptogenic. Sheng Li Xue Bao. 2004;56:163-71.

185. Keller JN, Steiner MR, Holtsberg FW, Mattson MP, Steiner SM. Lysophosphatidic acid-induced proliferation-related signals in astrocytes. J Neurochem. 1997;69:1073-84.

186. Moller T, Contos JJ, Musante DB, Chun J, Ransom BR. Expression and function of lysophosphatidic acid receptors in cultured rodent microglial cells. J Biol Chem. 2001;276:25946-52.

187. Awada R, Rondeau P, Gres S, Saulnier-Blache JS, Lefebvre d'Hellencourt C, Bourdon E. Autotaxin protects microglial cells against oxidative stress. Free Radic Biol Med. 2012;52:516-26.

188. Awada R, Saulnier-Blache JS, Gres S, Bourdon E, Rondeau P, Parimisetty A, et al. Autotaxin downregulates LPS-induced microglia activation and pro-inflammatory cytokines production. J Cell Biochem. 2014;115:2123-32.

189. Frugier T, Crombie D, Conquest A, Tjhong F, Taylor C, Kulkarni T, et al. Modulation of LPA receptor expression in the human brain following neurotrauma. Cell Mol Neurobiol. 2011;31:569-77.

190. Hecht JH, Weiner JA, Post SR, Chun J. Ventricular zone gene-1 (vzg-1) encodes a lysophosphatidic acid receptor expressed in neurogenic regions of the developing cerebral cortex. J Cell Biol. 1996;135:1071-83.

191. Yau SY, Li A, Hoo RL, Ching YP, Christie BR, Lee TM, et al. Physical exercise-induced hippocampal neurogenesis and antidepressant effects are mediated by the adipocyte hormone adiponectin. Proc Natl Acad Sci U S A. 2014;111:15810-5.

192. Weisberg SP, McCann D, Desai M, Rosenbaum M, Leibel RL, Ferrante Jr AW. Obesity is associated with macrophage accumulation in adipose tissue. J Clin Invest. 2003:112:1796-808.

193. Greenberg AS, Obin MS. Obesity and the role of adipose tissue in inflammation and metabolism. Am J Clin Nutr. 2006:83:461S-5.

194. Moschen AR, Kaser A, Enrich B, Mosheimer B, Theurl M, Niederegger $H$, et al Visfatin, an adipocytokine with proinflammatory and immunomodulating properties. J Immunol. 2007;178:1748-58.

195. Tilg H, Moschen AR. Adipocytokines: mediators linking adipose tissue, inflammation and immunity. Nat Rev Immunol. 2006;6:772-83.

196. Clement K, Viguerie N, Poitou C, Carette C, Pelloux V, Curat CA, et al. Weight loss regulates inflammation-related genes in white adipose tissue of obese subjects. FASEB J. 2004;18:1657-69.

197. Berg AH, Scherer PE. Adipose tissue, inflammation, and cardiovascular disease. Circ Res. 2005;96:939-49.

198. Takeda S, Sato N, Morishita R. Systemic inflammation, blood-brain barrier vulnerability and cognitive/non-cognitive symptoms in Alzheimer disease: relevance to pathogenesis and therapy. Front Aging Neurosci. 2014;6:171.

199. Mauro C, De Rosa V, Marelli-Berg F, Solito E. Metabolic syndrome and the immunological affair with the blood-brain barrier. Front Immunol. 2014;5:677

200. Gustafson DR, Karlsson C, Skoog I, Rosengren L, Lissner L, Blennow K. Midlife adiposity factors relate to blood-brain barrier integrity in late life. J Intern Med. 2007;262:643-50.

201. Kanoski SE, Zhang Y, Zheng W, Davidson TL. The effects of a high-energy diet on hippocampal function and blood-brain barrier integrity in the rat. J Alzheimers Dis. 2010;21:207-19.
202. Wisse LE, Reijmer YD, ter Telgte A, Kuijf HJ, Leemans A, Luijten PR, Koek HL, Geerlings MI, Biessels GJ, Utrecht Vascular Cognitive Impairment Study G. Hippocampal disconnection in early Alzheimer's disease: a 7 tesla MRI study. J Alzheimers Dis. 2015:45:1247-1256.

203. Remy F, Vayssiere N, Saint-Aubert L, Barbeau E, Pariente J. White matter disruption at the prodromal stage of Alzheimer's disease: relationships with hippocampal atrophy and episodic memory performance. Neuroimage Clin. 2015;7:482-92.

204. Whitwell JL. Progression of atrophy in Alzheimer's disease and related disorders. Neurotox Res. 2010;18:339-46.

205. Bowman GL, Kaye JA, Moore M, Waichunas D, Carlson NE, Quinn JF. Blood-brain barrier impairment in Alzheimer disease: stability and functional significance. Neurology. 2007;68:1809-14.

206. Ujiie M, Dickstein DL, Carlow DA, Jefferies WA. Blood-brain barrier permeability precedes senile plaque formation in an Alzheimer disease model. Microcirculation. 2003;10:463-70.

207. Gardener SL, Rainey-Smith SR, Martins RN. Diet and inflammation in Alzheimer's disease and related chronic diseases: a review. J Alzheimers Dis. 2015;50:301-34.

208. Matsuda M, Shimomura I. Roles of adiponectin and oxidative stress in obesity-associated metabolic and cardiovascular diseases. Rev Endocr Metab Disord. 2014;15:1-10.

209. Laurikka A, Vuolteenaho K, Toikkanen V, Rinne T, Leppanen T, Tarkka M, et al. Adipocytokine resistin correlates with oxidative stress and myocardial injury in patients undergoing cardiac surgery. Eur J Cardiothorac Surg. 2014;46:729-36.

210. Furukawa S, Fujita T, Shimabukuro M, Iwaki M, Yamada Y, Nakajima Y, et al. Increased oxidative stress in obesity and its impact on metabolic syndrome. J Clin Invest. 2004;114:1752-61.

211. Vachharajani $V$, Granger DN. Adipose tissue: a motor for the inflammation associated with obesity. IUBMB Life. 2009;61:424-30.

212. Fernandez-Sanchez A, Madrigal-Santillan E, Bautista M, Esquivel-Soto J, Morales-Gonzalez A, Esquivel-Chirino C, et al. Inflammation, oxidative stress, and obesity. Int J Mol Sci. 2011;12:3117-32.

213. Ozata M, Mergen M, Oktenli C, Aydin A, Sanisoglu SY, Bolu E, et al. Increased oxidative stress and hypozincemia in male obesity. Clin Biochem. 2002:35:627-31.

214. Vincent HK, Vincent KR, Bourguignon C, Braith RW. Obesity and postexercise oxidative stress in older women. Med Sci Sports Exerc. 2005;37:213-9.

215. Pihl E, Zilmer K, Kullisaar T, Kairane C, Magi A, Zilmer M. Atherogenic inflammatory and oxidative stress markers in relation to overweight values in male former athletes. Int J Obes (Lond). 2006;30:141-6.

216. Gandhi S, Abramov AY. Mechanism of oxidative stress in neurodegeneration. Oxid Med Cell Longev. 2012;2012:428010.

217. Morrow JD. Is oxidant stress a connection between obesity and atherosclerosis? Arterioscler Thromb Vasc Biol. 2003;23:368-70.

218. Rodriguez-Rodriguez A, Egea-Guerrero JJ, Murillo-Cabezas F, Carrillo-Vico A. Oxidative stress in traumatic brain injury. Curr Med Chem. 2014:21:1201-11.

219. Ruszkiewicz J, Albrecht J. Changes in the mitochondrial antioxidant systems in neurodegenerative diseases and acute brain disorders. Neurochem Int. 2015;88:66-72.

220. Esposito K, Ciotola M, Schisano B, Misso L, Giannetti G, Ceriello A, et al. Oxidative stress in the metabolic syndrome. J Endocrinol Invest 2006;29:791-5

221. Freeman LR, Keller JN. Oxidative stress and cerebral endothelial cells: regulation of the blood-brain-barrier and antioxidant based interventions. Biochim Biophys Acta. 1822;2012:822-9.

222. Lochhead JJ, McCaffrey G, Quigley CE, Finch J, DeMarco KM, Nametz N, et al. Oxidative stress increases blood-brain barrier permeability and induces alterations in occludin during hypoxia-reoxygenation. J Cereb Blood Flow Metab. 2010:30:1625-36.

223. Enciu AM, Gherghiceanu M, Popescu BO. Triggers and effectors of oxidative stress at blood-brain barrier level: relevance for brain ageing and neurodegeneration. Oxid Med Cell Longev. 2013;2013:297512. 